\title{
Workshop Pengumpulan dan Visualisasi Data Online Survei Kepuasan Masyarakat terhadap Pelayanan Puskesmas di Lombok Tengah
}

\author{
Moh Ali', Menap Menap ${ }^{2}$ \\ ${ }^{1}$ Program Magister Kesehatan, 2Program Magister Administrasi Kesehatan, Fakultas Kesehatan, Universitas Qamarul \\ Huda Badarudin \\ Turmuzi Badrudin, Bagu, Praya, Central Lombok Regency, West Nusa Tenggara, 83371, Indonesia
}

\begin{abstract}
ARTICLE INFO
Received: 2021-01-09

Revised: 2021-03-04

Accepted: 2021-04-26

Keywords:

Collection, Health center, Online,

Satisfaction, survey,

ABSTRACT

Many people feel helped by the health center services and there are also people who are not satisfied. The Community Satisfaction Survey (SKM) was conducted to determine the quality of services provided by community health centers. For government-owned public service providers, the Minister of PANRB issued a regulation on SKM Number 14 of 2017. Based on information from the Head of the Primary Health Care Section of the Central Lombok Regency Health Office in 2019 only 6 puskesmas out of 28 puskesmas conducted a survey but the documents sent did not comply with the guidelines. This is because the puskesmas do not understand the benefits of SKM, have not received socialization, do not yet understand the techniques for conducting SKM and the calculation of survey results. The solution offered in this workshop is to provide knowledge about SKM, about the 9 elements of public service quality that determine satisfaction, providing skills in collecting and visualizing online data from survey results. The results obtained from this activity were an increase in the knowledge and skills of public health centers regarding SKM and the implementation of online data collection and visualization of the Community Satisfaction Survey went well.
\end{abstract}

Visualization
(C)2021 Published by University of Merdeka Malang. This is an open access article distributed under the CC BY-SA 4.0 license (https://creativecommons.org/licenses/by-sa/4.0/)

How to cite: Ali, M., \& Menap, M. (2021). Workshop Pengumpulan dan Visualisasi Data Online Survei Kepuasan Masyarakat terhadap Pelayanan Puskesmas di Lombok Tengah. Abdimas: Jurnal Pengabdian Masyarakat Universitas Merdeka Malang, 6(2), 279-289. https://doi.org/10.26905/abdimas.v6i2.5384

\section{PENDAHULUAN}

Pelayanan adalah suatu proses melayani kebutuhan orang atau konsumen agar kebutuhannya terpenuhi dan masalahnya teratasi, untuk itu pelayan yang diberikan haruslah pelayanan yang berkualitas. Pelayanan yang berkualitas adalah pelayanan yang dilaksanakan sesuai standar yang telah ditentukan. Menurut UU RI Nomor 25 Tahun 2009 Tentang Pelayanan Publik, pelayanan yang berkualitas paling sedikitnya memenuhi beberapa standar berikut, yaitu dasar hukum, persyaratan, prosedur, biaya, waktu 
ABDIMAS: Jurnal Pengabdian Masyarakat Universitas Merdeka Malang

Volume 6, No. 2, May 2021: 279-289

pelayanan, kompetensi petugas, perilaku petugas, pengawasan internal, jumlah pelaksana, produk pelayanan, pengelolaan pengaduan, jaminanan pelayanan, jaminan keamanan, dan sarana prasarana.

Jika puskesmas ingin memberikan pelayanan yang berkualitas kepada masyarakat maka pelayanan tersebut harus memuaskan masyarakat. Pelayanan yang memuaskan akan terjadi jika Penyelenggara pelayanan memahami kebutuhan konsumen. Konsumen akan merasa puas jika apa yang diharapkan sesuai dengan kenyataan (Feigenbaum,1986) Dengan demikian Kualitas itu adalah kepuasan konsumen (Ishikawa, 1986). Hasil ini sejalan dengan penelitian yang dilaksanakan oleh Radito (2014) menyatakan semakin tinggi kualitas pelayanan diberikan oleh pihak puskesmas maka akan semakin tinggi kepuasan para pasien yang berobat ke puskesmas.

Puskesmas adalah fasilitas kesehatan tingkat pertama milik pemerintah yang berfungsi memberikan pelayanan kesehatan kepada masyarakat, berupa Upaya Kesehatan Perorangan (UKP) dan Upaya Kesehatan Masyarakat (UKM) dalam bentuk kegiatan promotif, preventif, kuratif, dan rehabilitatif. Karena yang dilayani masyarakat, maka dari itu puskesmas disebut juga sebagai penyelenggara pelayanan publik (Permenkes Nomor 43 Tahun 2019).

Sebagian besar masyarakat jika membutuhkan pelayanan kesehatan kontak pertamanya adalah dengan puskesmas. Banyak masyarakat yang merasa terbantu dengan pelayanan di puskesmas tapi tidak sedikit juga masyarakat yang merasa belum puas terhadap pelayanan puskesmas. Hal ini ditandai dengan timbulnya beberapa permasalahan antara petugas puskesmas dengan masyarakat, adanya protes-protes yang disampaikan langsung ke puskesmas, yang disampaikan di sosial media dan media surat khabar maupun media elektronik lainya. Permasalahan utama yang terjadi terhadap penyelenggara pelayanan publik adalah melupakan standar. Jika permasalahan ini tidak segera diatasi akan memberikan dampak buruk bagi puskesmas, masyarakat tidak percaya dan akan meninggalkan puskesmas

Hal yang sangat penting yang harus dilakukan oleh puskesmas sebagai penyelenggara pelayanan publik dalam memberikan pelayanan yang dapat memuaskan masyarakat adalah melakukan perbaikanperbaikan terhadap kualitas pelayanan secara terus-menerus (Continuous Quality Improvement) agar tetap eksis dalam memberikan manfaat serta pelayanan yang terbaik bagi masyarakat (Wahyudi \& Hadikarya, 2016).

Perbaikan-perbaikan ini haruslah didasarkan oleh pemahaman Puskesmas terhadap permasalahan yang muncul di masyarakat, memahami kebutuhan atau harapan masyarakat. Salah satu upaya yang perlu dilakukan adalah melakukan survei kepuasan masyarakat untuk mengetahui apakah pelayanan yang kita berikan sudah berkualitas atau belum. Indikasi pelayanan yang berkualitas adalah kepuasan masyarakat. Apabila anda ingin sukses, yang harus anda lakukan adalah membuat konsumen anda puas. Jika mereka sudah puas apapun yang anda tawarkan akan mereka beli, untuk itu perlu dilakukan survei kepuasan pelanggan untuk mengetahui apakah pelanggan puas atau tidak (Islamiyati, 2014).

Dalam melakukan survei kepuasan masyarakat, pemerintah melalui Kementrian Pendayagunaan Aparatur Negara Reformasi dan Birokrasi telah mengeluarkan pedoman. Pedoman ini tertuang dalam Peraturan Menteri Pendayagunaan Aparatur Negara Nomor 14 tahun 2017. Pedoman ini adalah pedoman standar bagi penyelenggara pelayanan publik milik pemerintah diseluruh Indonesia termasuk didalamnya adalah puskesmas. Didalam pedoman ini memuat 9 (Sembilan) unsur kualitas pelayanan sebagai alat 
ukur untuk mengetahui indeks kepuasan masyarakat, terdapat rumus rumus dalam perhitungan Indeks kepuasan masyakat, teknik perhitungan sampel terhadap populasi, terdapat kuesioner, terdapat tabel Morgan, dan pedoman penyusunan laporan hasil survei kepuasan.

Pada Dinas Kesehatan Kabupaten Lombok Tengah pelaksanaan survei kepuasan masyarakat masih belum berjalan dengan baik. Berdasarkan hasil informasi dari Kepala Seksi Yankes Primer, Dinas Kesehatan Kabupaten Lombok Tengah, sejauh ini dari 28 puskesmas yang ada di Lombok Tengah pada tahun 2019 hanya 6 puskesmas atau sebesar 20\% puskesmas yang melaporkan hasil survei kepuasan masyarakat dan dokumen yang dilaporkan tidak mengikuti kaedah atau pedoman yang ada di Peraturan Menteri Pendayagunaan Aparatur Negara Nomor 14 Tahun 2017 Tentang Pedoman Penyusunan Survei Kepuasan Masyarakat.

Berdasarkan hasil studi lapangan di beberapa puskesmas, didapatkan informasi sebagai berikut: (1) Kurangnya pemahaman puskesmas tentang manfaat survei kepuasan masyarakat; (2) Puskesmas belum mendapatkan sosialisasi tentang survei kepuasan masyarakat dari Dinas Kesehatan Kabupaten Lombok Tengah; (3) Puskesmas belum memahami teknik melakukan survei kepuasan masyarakat dan perhitungan hasil survei; (4) Belum terbentuknya tim survei di puskesmas sehingga survei belum berjalan sesuai harapan.

Berdasarkan analisis situasi di atas, diperlukan sosialisasi tentang survei kepuasan masyarakat yang efektif dan efisien melalui workshop pengumpulan dan visualisasi data online survei kepuasan masyarakat bagi puskesmas di lingkup Dinas Kesehatan Kabupaten Lombok Tengah. Metode ini mampu menghasilkan data yang cepat dan tepat serta menghasilkan grafik-grafik yang menarik dan mudah untuk dilakukan interpretasi.

Solusi yang ditawarkan dalam kegiatan workshop ini adalah: (1) Memberikan pengetahuan tentang pentingnya melakukan survei kepuasan masyarakat bagi puskesmas; (2) Memberikan pengetahuan tentang unsur-unsur kualitas pelayanan publik yang menentukan kepuasan masyarakat; (3) Memberikan pengetahuan dan keterampilan dalam pengumpulan dan visualisasi data online hasil survei kepuasan masyarakat.

Tujuan dari diadakannya kegiatan workshop ini adalah memberikan pemahaman kepada puskesmas tentang pentingnya survei kepuasan masyarakat, tersusunnya mekanisme survei kepuasan masyarkat yang efektif dan efesien bagi puskesmas lingkup Dinas Kesehatan Kabupaten Lombok Tengah, terkumpulnya data survei dengan cepat dan visualisasi data dalam bentuk tabel dan grafik yang realtime dan menarik sehingga memudahkan dalam proses analisis.

\section{METODE}

Kegiatan workshop ini dilaksanakan di 28 puskesmas lingkup Dinas Kesehatan Kabupaten Lombok Tengah, dengan peserta kepala puskesmas, kepala tata usaha, petugas poli umum, petugas UGD, petugas rawat inap, petugas poli gigi, petugas KIA, petugas laboratorium, petugas farmasi, semua petugas pustu, dan bidan desa. Workshop berlangsung pada November-Desember 2020. 
ABDIMAS: Jurnal Pengabdian Masyarakat Universitas Merdeka Malang

Volume 6, No. 2, May 2021: 279-289

Pendekatan yang digunakan dalam kegiatan pengabdian ini adalah Participant Active Learning (PAL) karena diharapkan semua peserta berpartisipasi secara aktif dalam kegiatan workshop. Sedangkan bentuk kegiatan pengabdian ini adalah pelatihan interaktif sehingga terjadi interaksi dua arah antara tim pengabdian dan peserta kegiatan. Hal ini bertujuan untuk memberikan kesempatan kepada petugas kesehatan untuk menyumbangkan ide, gagasan, pendapat, pikiran, kreativitas, dan pengalamannya dalam kegiatan pengumpulan data dan visualisasi data online survei kepuasan masyrakat.

Metode yang digunakan dalam workshop berdasarkan pendekatan tersebut antara lain: (1) Presentasi. Presentasi adalah metode yang digunakan untuk menyampaikan materi pelatihan. Materi disajikan dalam bentuk slide (Power Point); (2) Tanya jawab. Tanya jawab adalah metode penyampaian materi dengan tanya jawab dilakukan dengan tujuan memberikan kejelasan suatu informasi/pengetahuan dan konsep; (3) Praktik. Praktik adalah pelaksanaan secara nyata apa yang didapatkan dalam teori (KBBI online). Tahap ini peserta melakukan 3 kali praktik yaitu melakukan praktik wawancara, praktik visualisasi data online, dan praktik interpretasi hasil survei; (4) Pelaksanaan survei kepuasan masyarakat. Pelaksanaan survei kepuasan masyarakat akan dilaksanakan segara setelah workshop berakhir. Pendamping bersamasama dengan peserta menentukan jumlah populasi, menentukan jumlah sampel dan menentukan lokasi unit pelayanan yang akan di survei di puskesmas dan lamanya survei. Yang menjadi populasi adalah seluruh masyarakat yang kontak dalam satu bulan terkahir di puskesmas, penentuan jumlah sampel adalah dengan mengkonversi jumlah populasi dengan tabel Sampel Morgan dan Krejcie Lokasi survei yang disepakati adalah pada poli umum, poli gigi, poli KIA/bersalin, UGD, ruang rawat inap, laboratorium, puskesmas pembantu, Polindes, dan Puskesmas Keliling (Puskel). Lamanya waktu yang dibutuhkan ratarata 7 sampai dengan 10 hari; (5) Monitoring dan evaluasi. Pendamping melakukan monitoring dan evaluasi hasil survei setiap saat. Monitoring dan evaluasi ini dilakukan secara online yaitu memantau jumlah responden yang berhasil disurvei pada dashboard (papan data) masing-masing puskesmas, pendamping memberikan feedback hasil pelaksanaan survei dan memberikan apresiasi terhadap puskesmas yang telah melaksanakan survei tepat waktu; (6) Rancangan evaluasi keberhasilan. Dalam kegiatan workshop ini ada 3 kriteria keberhasilan yang dijadikan tolok ukur keberhasilan kegiatan workshop. Tolak ukur keberhasilan dari pelaksanaan kegiatan adalah pelaksanaan kegiatan sesuai dengan jadwal yang telah ditentukan sehingga perlu adanya kerjasama yang baik antara pelaksana dengan peserta. Tolak ukur keberhasilan dari pihak peserta antara lain adalah peserta memiliki pengetahuan dan menerapkan kegiatan survei kepuasan masyarakat di puskesmas atau unit pelayanan sesuai dengan jumlah sampel yang ditetapkan. Tolak ukur keberhasilan dari pihak pelaksana adalah mampu memberikan penjelasan dan bantuan kepada puskesmas dalam pelaksanaan survei di puskesmas.

\section{HASIL DAN PEMBAHASAN}

\section{Hasil}

Penyampaian materi tentang survei kepuasan masyarakat ini disampaikan dengan menggunakan slide Power Point, dengan metode ceramah dan tanya jawab. Salah satu metode untuk meningkatkan pengetahuan adalah dengan menggunakan media slide presentasi Power Point. Hal ini sesuai dengan hasil 
penelitian Suarno (2012) motivasi dan hasil belajar siswa mengalami peningkatan dengan menggunakan slide presentasi. Didukung juga oleh penelitian Nurhidayat (2012), dengan menggunakan media slide presentasi Power Point dapat meningkatkan pengetahuan kesehatan gigi dan mulut pada siswa SD. Gambar 1 menyajikan kegiatan pendamping saat melakukan presentasi.

Materi yang disampaikan meliputi: (1) Regulasi yang mengatur mekanisme survei kepuasan masyarakat bagi penyelenggara pelayanan publik yaitu Peraturan Menteri Pendayagunaan Aparatur Negara Reformasi dan Birokras; (2) 9 unsur kualitas pelayanan publik sebagai tolak ukur kepuasan masyarakat; (3) Manfaat dilakukannya survei; (4) Cara penentuan sampel, lokasi survei, dan periode survei; (5) Cara mengumpulkan data serta cara interpretasi hasil survei berdasarkan grafik-grafik.

Sebelum materi disampaikan, dilakukan pengukuran pengetahuan dan keterampilan tentang survei kepuasan masyarakat dengan cara peserta diminta untuk menjawab beberapa pertanyaan. Pertanyaan yang diajukan terdiri dari 6 pertanyaan tentang pengetahuan meliputi: (1) Regulasi yang mengatur pelaksanaan survei kepuasan masyarakat; (2) Unsur-unsur survei kepuasan masyarakat; (3) Manfaat dilakukannya survei kepuasan masyrakat; (4) Periode survei kepuasan masyarakat dan lokasi survei kepuasan masyarakat; (5) Cara menentukan sampel, dan (6) Keterampilan cara interpretasi hasil survei. Hasil angket menunjukkan bahwa kegiatan workshop ini secara keseluruhan dapat meningkatkan pengetahuan peserta. Untuk lebih jelasnya dapat dilihat pada Gambar 2.

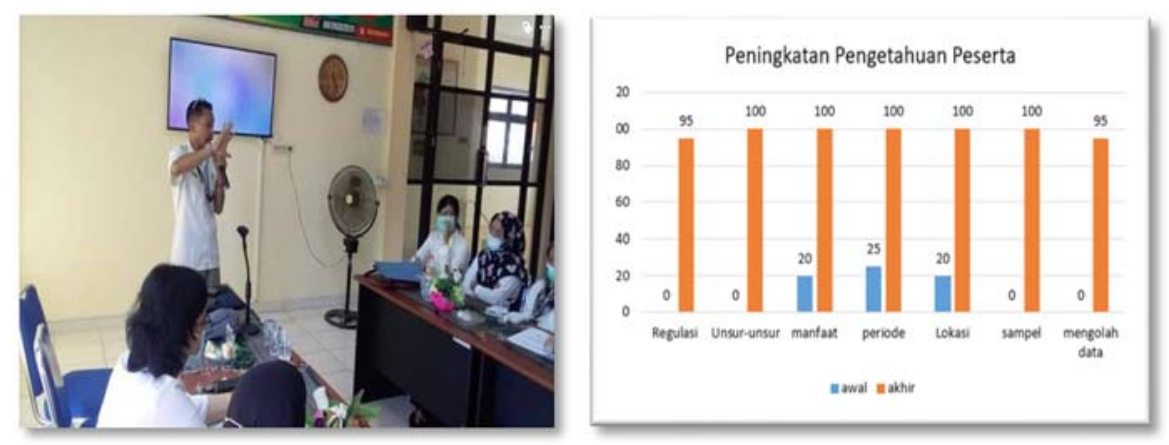

Gambar 1. Pemberian materi kepada peserta

Gambar 2. Peningkatan pengetahuan peserta workshop

Berdasarkan Gambar 2, dapat dilihat bahwa pengetahuan tentang regulasi yang mengatur tentang survei kepuasan masyarakat dari $0 \%$ meningkat menjadi $95 \%$ atau sebanyak 447 dari 470 peserta, pengetahuan tentang 9 (sembilan) unsur survei yang menjadi indikator kepuasan masyarakat juga meningkat dari $0 \%$ menjadi $100 \%$. Pengetahuan tentang manfaat survei kepuasan masyarakat juga meningkat dari $20 \%$ atau sekitar 94 orang dari 470 meningkat menjadi 100\%. Pengetahuan tentang priode survei juga meningkat dari $25 \%$ menjadi 100\% begitu juga dengan pengetahuan tentang lokasi survei juga meningkat dari $20 \%$ menjadi $100 \%$. Pengetahuan tentang cara menentukan sampel juga meningkat dari $0 \%$ menjadi $100 \%$ termasuk pengetahuan dan keterampilan melakukan interpretasi hasil survei berdasarkan grafik yang muncul juga meningkat dari $0 \%$ menjadi $100 \%$. 
ABDIMAS: Jurnal Pengabdian Masyarakat Universitas Merdeka Malang

Volume 6, No. 2, May 2021: 279-289

\section{Praktik wawancara}

Praktik wawancara adalah kegiatan latihan tanyajawab secara lisan di antara para peserta workshop. Hal ini bertujuan agar peserta saat wawancara yang sebenarnya dengan masyarakat dapat berjalan dengan lancar. Wawancara menggunakan 9 daftar pertanyaan tertutup dan 1 pertanyaan terbuka yang terdapat dalam Android yang disusun dalam bentuk Google Form. Dalam proses praktik wawancara ini, peserta menunjukkan kemampuan yang baik. Hal ini dikarenakan semua tenaga kesehatan sudah terbiasa berkomunikasi dengan masyarakat dan sebelum praktik wawancara peserta sudah dibekali dengan pengetahuan tentang survei kepuasan masyarakat. Salah satu faktor yang menyebabkan proses wawancara tersebut menjadi lancar adalah pengetahuan pewawancara. Gambar 3 adalah gambar saat latihan wawancara.

\section{Praktik visualisasi data online hasil survei}

Praktik ini dilakukan setelah semua peserta selesai melakukan praktik wawancara. Hasilnya akan terakumulasi dan terekam dalam bentuk Google Sheets. Selanjutnya data diolah dengan memanfaatkan aplikasi pengolahan data pada Datastudio. Semua tabel dan grafik ditampilkan dalam dashboard (papan data) puskesmas yang terdiri dari tabel jumlah sampel, jumlah responden yang berhasil disurvei, indeks kepuasan masyarakat dan kinerja puskesmas, 4 grafik demografi, 9 grafik unsur-unsur kepuasan, 1 grafik kesimpulan yang memuat 9 unsur, dan 1 tabel yang menggambar lokasi survei. Pendamping memberikan penjelasan tentang visualisasi data hasil survei termasuk cara mendownload hasil survei dan dilanjutkan dengan memberikan kesempatan kepada peserta untuk melakukan visualisasi dan mendownload hasil survei. Hasilnya menunjukkan bahwa semua peserta dapat menampilkan (visualisasi) data online hasil survei kepuasan masyarakat. Gambar 4 adalah salah satu gambar kegiatan dalam praktik visualisasi data.
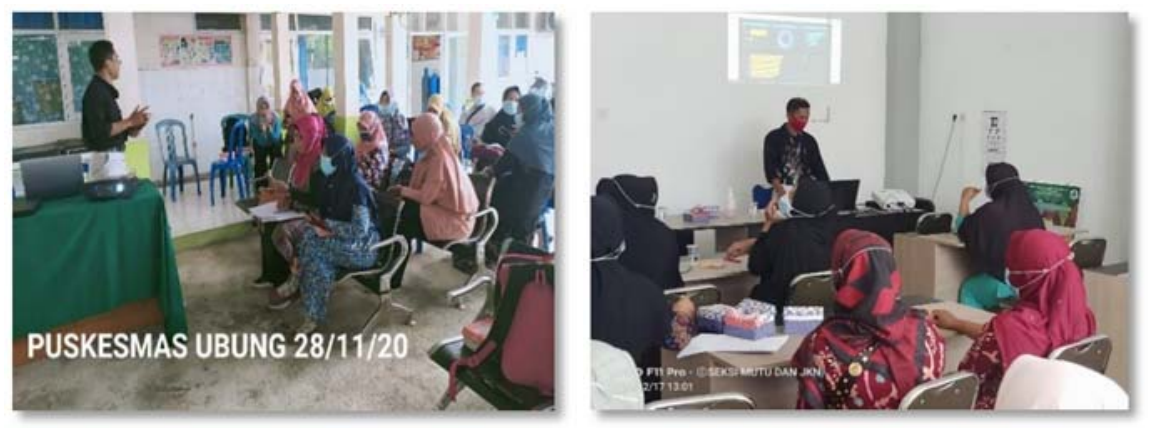

Gambar 3. Praktik wawancara

Gambar 4. Praktik visualisasi data online

\section{Praktik interpretasi hasil survei}

Praktik ini adalah kegiatan memahami makna atau informasi yang terdapat pada grafik-grafik hasil survei kepuasan. Grafik-grafik yang di interpretasi adalah grafik hasil praktik wawancara hasil olahan aplikasi Datastudio yang ditampilkan dalam dashboard (papan data) puskesmas. Grafik-grafik ini akan berubah otomatis sesuai dengan perubahan data yang masuk. Dengan demikian, puskesmas tidak lagi 
membuat grafik manual. Kegiatan praktik ini diawali dengan penjelasan dari pendamping selanjutnya diberikan kesempatan kepada peserta untuk melakukan interpretasi. Hasil praktik menunjukkan bahwa semua peserta dapat melakukannya dengan baik.

\section{Pelaksanaan survei kepuasan masyarakat}

Kegiatan survei ini dilaksanakan serentak mulai dari bulan November sampai dengan Desember 2020 pada 28 puskesmas lingkup Dinas Kesehatan Kabupaten Lombok Tengah. Kuesioner disusun dalam bentuk Google Form linknya diberikan ke 28 puskesmas untuk digunakan sebagai instrumen pengumpulan data. Data yang terkumpul diolah secara online dengan bantuan aplikasi Datastudio.

Grafik-grafik hasil olahan online, hasil survei 28 puskesmas di lingkup Dinas Kesehatan Kabupaten Lombok Tengah dapat dilihat di link ini. Pada saat pembaca mengklik link tersebut maka akan muncul capaian hasil survei kepuasan masyarakat untuk tingkat kabupaten Lombok Tengah dan tersedia capaian hasil survei kepuasan masing-masing puskesmas. Grafik-grafik dibawah ini adalah grafik yang menunjukkan data hasil pelaksanaan survei kepuasan masyarakat di Kabupaten Lombok Tengah hasil pengolahan Datastudio.
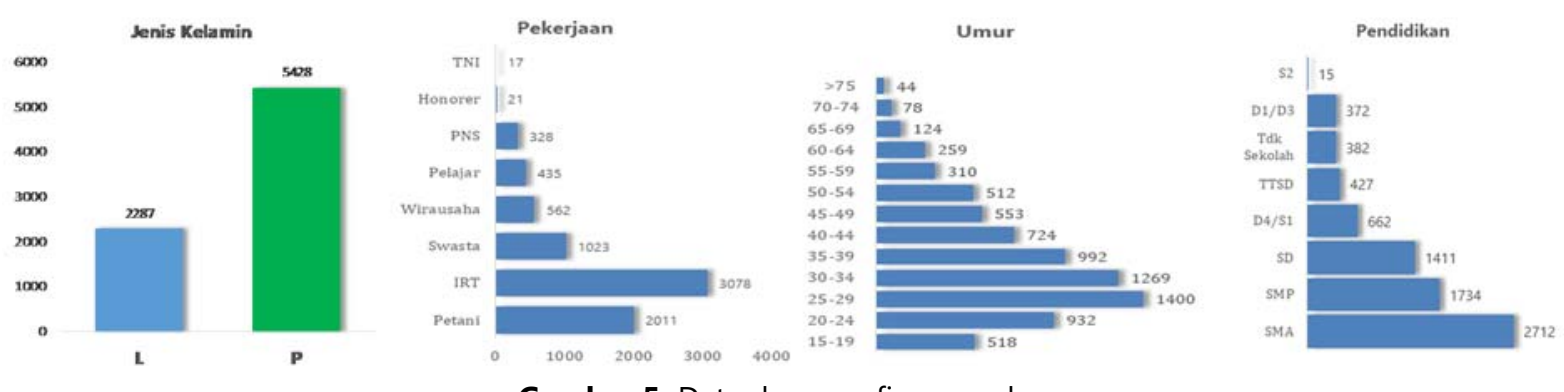

Gambar 5. Data demografi responden

Dari Gambar 5 dapat dijelaskan bahwa dari 7.715 sampel yang diwawancarai, 70,35\% adalah perempuan atau sejumlah 5428 sampel sedangkan 29,65\% adalah laki-laki atau sejumlah 2287 sampel, dengan pekerjaan tertinggi adalah Ibu Rumah Tangga sebesar 3078 (39,9\%), umur terbanyak adalah pada rentang usia 25-29 tahun sebesar $1400(18,1 \%)$ dan pendidikan tertinggi adalah SMA sebanyak 2712 (35,2\%). Untuk melihat kepuasan masyarakat terhadap 9 unsur kualitas pelayanan publik yang dilaksanakan oleh puskesmas dapat dilihat pada Gambar 6-8.
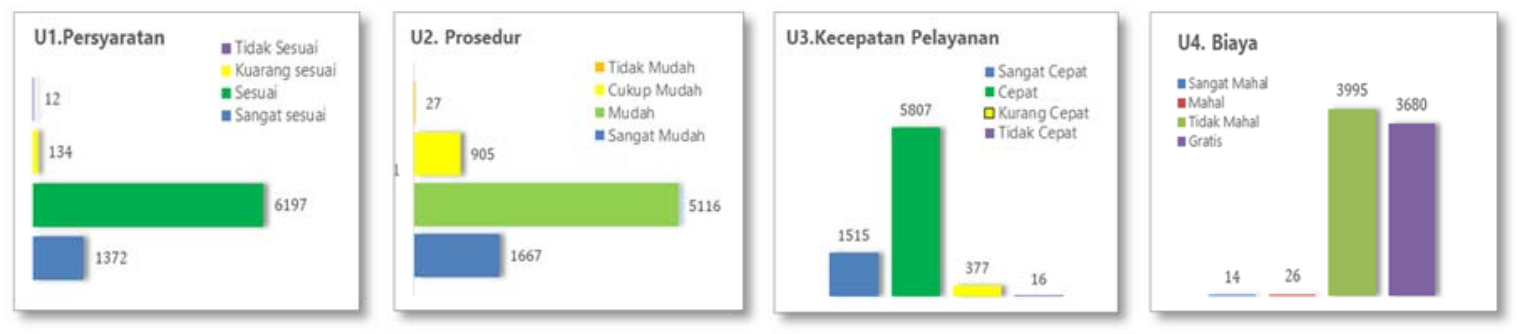

Gambar 6. Kualitas pelayanan publik unsur persyaratan, prosedur, kecepatan pelayanan, dan biaya 
ABDIMAS: Jurnal Pengabdian Masyarakat Universitas Merdeka Malang Volume 6, No. 2, May 2021: 279-289
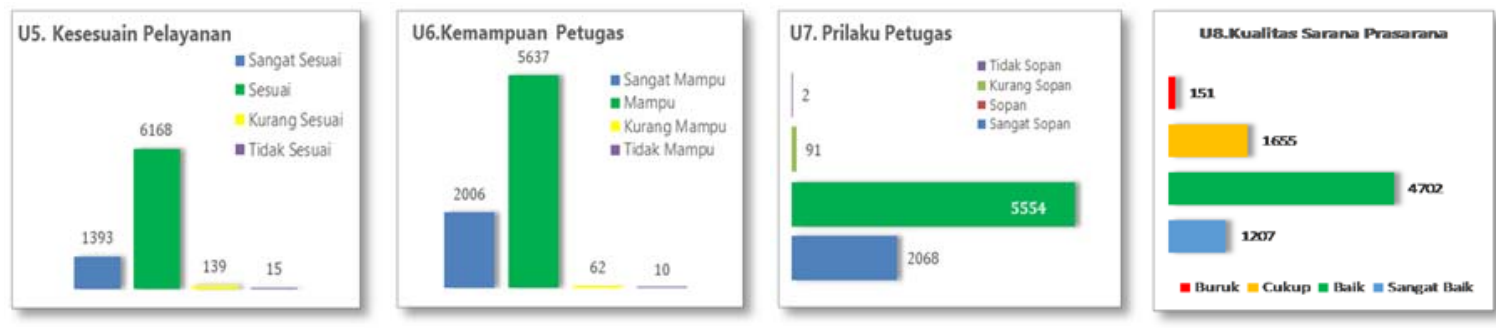

Gambar 7. Kualitas pelayanan publik unsur kesesuaian pelayanan, kemampuan petugas, perilaku petugas, dan kualitas sarana prasarana

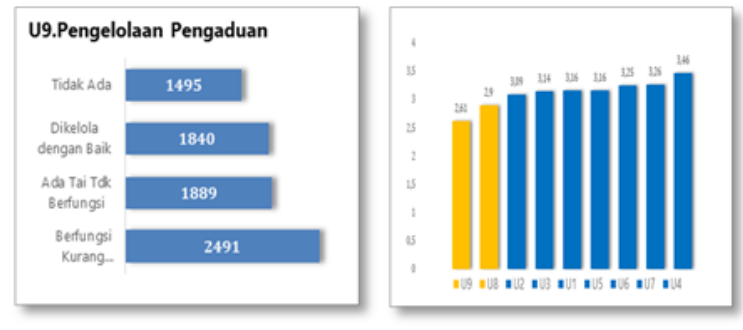

Gambar 8. Kualitas pelayanan publik unsur pengelolaan pengaduan, tingkat kepuasan per unsur

\section{Tingkat Kepuasan Per Unsur}

Dari Gambar 8 dapat dijelaskan bahwa, Indeks Kepuasan Masyarakat (IKM) sebesar 77,68, ini artinya mutu puskesmas di lingkup Dinas Kesehatan Kabupaten Lombok Tengah tergolong B dan kinerja puskesmas tergolong baik. Hasil pengolahan data 9 (sembilan) unsur kualitas pelayanan publik yaitu unsur persyaratan (U1), unsur prosedur (U2), unsur kecepatan pelayanan (U3), unsur biaya (U4), unsur kesesuaian pelayanan (U5), unsur kemampuan petugas (U6), unsur perilaku petugas (U7), unsur kualitas sarana prasarana (U8), dan unsur pengolahan keluhan (U9) dapat dijelaskan bahwa dari unsur persyaratan (U1) sampai dengan unsur prilaku petugas (U7) sudah memuaskan masyarakat dengan rentang skalanya 3 - <4. Sedangkan yang masih belum memuaskan masyarakat adalah unsur kualitas sarana prasarana (U8) dan unsur pengelolaan pengaduan (U9) dengan skala berada pada rentang $2-<3$. Menurut Peraturan Menteri Pendayagunaan Aparatur Negara Nomor 14 tahun 2017 dijelaskan bahwa hasil pengukuran survei kepuasan masyarakat adalah perubahan angka indeks. Angka ini ditetapkan dengan skala 1 (satu) sampai dengan 4 (empat). Jika skalanya 1 (satu) artinya tidak puas, jika skalanya 2 (dua) artinya cukup puas, jika skalanya 3 (tiga) artinya puas dan jika skalanya 4 (empat) artinya sangat puas.

\section{Monitoring dan evaluasi}

Kegiatan ini dilaksanakan oleh pendamping yang bekerjasama dengan mitra sebagai admin Dinkes Kabupaten Lombok Tengah yang setiap hari memantau hasil survei yang dilaksanakan oleh puskesmas. Jika terdapat puskesmas yang progresnya dalam survei kurang segera diberikan feedback ke 
kepala puskesmas melalui WA. Sejauh ini pelaksanaan pengumpulan data online dengan menggunakan kuesioner Google Form berjalan dengan baik.

\section{Pembahasan}

Kegiatan workshop dalam bentuk pelatihan pengumpulan dan visualisasi data secara online hasil survei kepuasan masyarakat yang dilaksanakan oleh puskesmas. Peserta kegiatan workshop ini adalah petugas poli umum, petugas UGD, petugas rawat inap, petugas KIA, petugas gigi, laboratorium, farmasi, petugas pustu dan Polindes yang berasal dari 28 Puskesmas lingkup Dinas Kesehatan Kabupaten Lombok Tengah. Kegiatan ini bertujuan untuk memberikan pemahaman kepada puskesmas tentang pentingnya survei kepuasan masyarakat, tersusunnya mekanisme survei kepuasan masyarakat yang efektif dan efesien bagi puskesmas, terkumpulnya data survei dengan cepat dan visualisasi data dalam bentuk tabel dan grafik yang realtime dan menarik sehingga memudahkan dalam proses analisis.

Hasil kegiatan menunjukkan peningkatan pengetahuan puskesmas tentang survei kepuasan masyarakat. Diharapkan dengan meningkatnya pengetahuan akan mempengaruhi sikap dan perilaku petugas kesehatan untuk terus berupaya memberikan pelayanan yang berkualitas yaitu pelayanan yang sesuai standar dan memberikan kepuasan kepada masyarakat, hal ini sesuai dengan penelitian yang dilakukan oleh (Layuk et al., 2017) dimana terdapat pengaruh positif dan signifikan pengetahuan, sikap, dan keterampilan secara simultan terhadap kepuasan pasien rawat Inap RS Labuang Baji Makassar.

Kegiatan praktik yang meliputi praktik wawancara, praktik visualisasi data online, dan praktik interpretasi hasil survei berdasarkan grafik berjalan dengan baik. Hal ini ditunjukkan dengan antusiasnya mereka dalam melaksanakan praktik dan yang lebih penting lagi pelaksanaan survei kepuasan masyarakat di 28 puskesmas berjalan dengan baik dan lancar. Data hasil pelaksanaan survei, kepuasan masyarakat terhadap kualitas pelayanan publik di puskesmas lingkup Dinas Kesehatan Kabupaten Lombok Tengah berdasarkan Gambar 2 rata-rata berada pada skala 3,0644 - 3,532 dengan skala ini menunjukkan bahwa masyarakat di Lombok Tengah sudah merasa puas terhadap pelayanan yang diterima. Tetapi yang masih memerlukan perhatian dan segera untuk ditindaklanjuti adalah unsur penanganan pengaduan (U9) dan unsur sarana prasarana (U8) karena kedua unsur ini berdasarkan hasil survei berada pada skala 2,60 3,064 artinya kedua unsur ini masyarakat masih merasa kurang puas. Hal ini sesuai dengan penelitian yang dilkakan oleh (Pundenswari, 2017) menunjukkan bahwa kualitas pelayanan berpengaruh secara postitif dan signifikan terhadap kepuasan masyarakat.

Hasil visualisasi data seperti yang tampak pada Gambar 6-8 adalah hasil pengumpulan data online dengan kuesioner google form dan pengolahan data menggunakan aplikasi Datastudio. Dengan demikian aplikasi ini sangatlah bermanfaat bagi puskesmas karena puskesmas tidak lagi membuat grafik manual yang cukup membingungkan.

\section{SIMPULAN DAN SARAN}

Workshop ini bertujuan untuk memberikan pemahaman puskesmas tentang pentingnya survei kepuasan masyarakat, tersusunnya mekanisme survei kepuasan masyarkat yang efektif dan efesien bagi 
ABDIMAS: Jurnal Pengabdian Masyarakat Universitas Merdeka Malang

Volume 6, No. 2, May 2021: 279-289

puskesmas, terkumpulnya data survei dengan cepat, tergambarnya visualisasi data dalam bentuk tabel dan grafik yang realtime dan menarik sehingga memudahkan dalam proses analisis. Target yang hendak dicapai adalah puskesmas mampu melaksanakan survei kepuasan masyarakat dengan baik secara periodik, puskesmas mampu melakukan interpretasi hasil survei atas dasar grafik dan tabel. Workshop ini dilaksanakan dengan tahapan-tahapan sebagai berikut mengukur pengetahuan peserta tentang survei kepuasan masyarakat (pre-test dan post-test), memberikan materi tentang survei kepuasan masyarakat, pengumpulan data dengan kuesioner Google Form dan pengolahan data dengan aplikasi Datastudio, praktik wawancara, praktik interpretasi grafik, pelaksaan survei kepuasan masyarakat, monitoring, dan evaluasi survei kepuasan masyarakat. Diharapkan dengan adanya workshop ini semua puskesmas di lingkup Dinas Kesehatan Kabupaten Lombok Tengah secara rutin melakukan survei kepuasan masyarakat, dokumen hasil survei kepuasan masyarakat dapat tersusun dengan dan hasil survei dijadikan bahan evaluasi untuk perbaikan dan peningkatan kualitas pelayanan di puskesmas.

Perlu dilakukannnya sosialisasi mekanisme pengumpulan dan visualisasi data online survei kepuasan masyarakat ke SKPD lain yang menyelenggarakan pelayanan publik di lingkup Kabupaten Lombok Tengah seperti di dinas dukcapil, kantor camat, pembuatan SIM di kepolisian, perpajakan, kantor desa, RS dan lain-lain. Dari hasil pengumpulan dan visualisasi secara online maka hasil survei kepuasan masyarakat di Kabupaten Lombok Tengah akan terkumpul cepat dan visualisasi datanya akan sama, sehingga memudahkan dalam interpretasi hasil survei. Perlu dikembangkan dalam bentuk perangkat survei kepuasan masyarakat digital berbentuk layar sentuh yang ditempatkan di setiap unit penyelenggara pelayanan publik sehingga masyarakat setelah selesai diberikan pelayanan dapat langsung memberikan penilaian kualitas pelayanan yang telah diberikan.

\section{DAFTAR PUSTAKA}

Feigenbaum, A. V. (1986). Total Quality Control. (3 ${ }^{\text {rd }}$ Ed.). Singapore: McGraw-Hill.

Ishikawa, K. (1986). Gugus Kendali Mutu dalam Realita. Jakarta: Lembaga Sarana Informasi Usaha dan Produktivitas.

Islamiyati, N. (2014). Mengetahui fungsi survei kepuasan pelanggan [Artikel Web]. Mebiso. Retrieved from: https://mebiso.com/mengetahui-fungsi-survei-kepuasaan-pelanggan/ (Diakses pada 22 Januari 2021)

Layuk, E., Tamsah, H., \& Kadir, I. (2017). Pengaruh pengetahuan, sikap dan keterampilan perawat terhadap kepuasan pasien rawat inap di RS Labuang Baji Makassar. Jurnal Mirai Management, 2(2), 319337. https://doi.org/10.1234/mirai.v2i2.60

Nurhidayat, O. (2012). Perbandingan media Power Point dengan flip chart dalam meningkatkan pengetahuan kesehatan gigi dan mulut. Unnes Journal of Public Health, 1(1), 31-35. https://doi.org/10.15294/ujph.v1i1.179

Pundenswari, P. (2017). Analisis pengaruh kualitas pelayanan publik bidang kesehatan terhadap kepuasan masyarakat. Jurnal Publik: Jurnal Ilmiah Bidang Ilmu Administrasi Negara, 11(1), 13-21. 
Workshop Pengumpulan dan Visualisasi Data Online Survei Kepuasan Masyarakat terhadap Pelayanan Puskesmas ... Moh Ali, Menap Menap

Peraturan Menteri Pendayagunaan Aparatur Negara Nomor 14 Tahun 2017 Tentang Pedoman Penyusunan Survei Kepuasan Masyarakat.

Peraturan Menteri Kesehatan Republik Indoensia Nomor 43 Tahun 2019 Tentang Pusat Kesehatan Masyarakat.

Radito, T. (2014). Analisis pengaruh kualitas pelayanan dan fasilitas kesehatan terhadap kepuasan pasien Puskesmas. Jurnal Ilmu Manajemen, 11(2), 1-25. https://doi.org/10.21831/jim. v11i2.11753

Suarno, D. T. (2012). Upaya meningkatkan motivasi dan hasil belajar siswa dengan penerapan media slide Powerpoint pada mata pelajaran IPS Kelas VII A SMP Negeri 3 Sleman [Thesis]. Universitas Negeri Yogyakarta.

Undang-Undang Republik Indonesia Nomor 25 Tahun 2009 Tentang Pelayanan Publik.

Wahyudi, D., \& Hadikarya, F. (2016, Juni 21). Perbaikan terus-menerus dan fokus pada kualitas hasil kerja sebagai jalan menuju kesempurnaan [Artikel Web]. Kementerian Keuangan Republik Indonesia. Retrieved from: https://www.djkn.kemenkeu.go.id/artikel/baca/10676/PerbaikanTerus-Menerus-Dan-Fokus-Pada-Kualitas-Hasil-Kerja-Sebagai-Jalan-Menuju-Kesempurnaan. html 